\title{
Nazik Al-Malaika: The Poetess of Common People
}

\author{
Mohammed Raysul Hoque \\ Department of Arabic, Anwarul Ulum Senior Madrassa, Karimganj, India
}

Email address:

mrch2009@gmail.com,raysul20@yahoo.com

\section{To cite this article:}

Mohammed Raysul Hoque. Nazik Al-Malaika: The Poetess of Common People. Arabic Language, Literature \& Culture. Vol. 4, No. 4, 2019, pp. 72-76. doi: 10.11648/j.allc.20190404.12

Received: October 1, 2019; Accepted: November 29, 2019; Published: December 10, 2019

\begin{abstract}
Al-Malaika was born in Baghdad to a cultured family. Her mother was also a poetess and her father was a teacher as well as a writer. Nazik Al-Malaika (23 August 1923 - 20 June 2007) was an Iraqi female poetess and is considered by many to be one of the most influential contemporary Iraqi female poets and her poetic attitude depict her as a poetess of common people. Al-Malaika is famous as the first Arabic poet to use free verse system of poetry. She wrote her first poem at the age of mere 10only. Al-Malaika completed a master's degree in comparative literature from the University of Wisconsin-Madison with a Degree of Excellence. She entered the Institute of Fine Arts and graduated from the Department of Music in 1949. She was appointed as professor at the University of Baghdad, the University of Basrah, and Kuwait University respectively. Al-Malaika left Iraq in 1970 with her husband Abdel Hadi Mahbooba and family, following the rise of the Arab Socialist Ba'ath Party of Iraq to power. She lived in Kuwait until Saddam Hussein's invasion in 1990. Al-Malaika and her family left for Cairo, where she lived for the rest of her life. Naziks poetry primly illustrated the issues of common folks. Towards the end of her life, Al-Malaika suffered from a number of health issues, including Parkinson's disease. She died in Cairo in 2007 at the age of 83. Al-Malaika published several books of poems like; 'and the sea changes its color' in 1970, and "The Night's Lover".
\end{abstract}

Keywords: Al-Malaika, Poetess, Common People, Free Verse, Arabic Language, Literature, Iraq

\section{Introduction}

The Iraqi poetess Nazik-Al-Malaika is mainly noted for pioneering the free verse movement in Arabic literature. She was born in a genteel and literary family in Baghdad. Nazik grew up in a large and sprawling house hold of Iraq. Her parents were both poets, carefully nourished her and gave a modern education which helped her acquire ideas that sometimes shocked the rest of the family. Though Nazik had the strength of her convictions, she was a sensitive girl and any sort of criticism made her withdraw into the World of music and book, which were her favorite ones, and this attitude resulted in composing poems relating to common peoples day today issues. [1] She was born in 1923, and died in 2007. She was oldest among her four sisters and two brothers. Her father was a poet and the editor of a 20 volume encyclopedia. Her mother, Umme Nizar Al-Malaika on the other hand wrote poetry under the pseudonym against the British rule. Al-Malaika started writing from her childhood itself, and at the age of ten she composed the first poetry in classical Arabic. She was educated at the Higher Teachers
Training College in Baghdad, and completed graduation in 1944. [2] While still in college, she published poems in newspapers and magazines. As a student she was registered in the musical instrument Oudh (the idle eastern lute), department of the fine Arts in the acting department. Her knowledge of English literature earned her a scholarship to study at Princeton University, New Jersey.

Till 1954, Al-Malaika continued her studies at the University of Wisconsin, where she obtained Master's degree in literature. Afterwards she worked lecturer and professor in University. She married (In 1961) Abdel Hadi Mohbouba, her colleague in the Arabic department at the education college in Baghdad. [3] With her husband she helped in founding the 'University of Basra' in the Southern part of Iraq. Al-Malaika taught many years in the University of Kuwait, and in 1985 a festschrift appeared in her honor which contained twenty articles that depicted her work. In 1990 Al-Malaika was forced to return her home by Saddam's sudden invasion. After fleeing from Iraq in the after math of the Gulf war, she moved to Cairo, to continue as well as to uphold her zeal for literature and criticism. Although she has avoided publicity, Al-Malaika again entered in the arena of literature in 1999 with a new 
book of verse, the Bulk of the poems were written 25 years ago in 1974. [4] The book also contains all auto biographical sketches.

\section{Legacy of Nazik's Works}

Nazik, as a writer she made her debut in 1947 with 'Ashiqat Al-layl', which revolves around the themes of despair and disillusion. These aspects were familiar to the then Arabic literary romanticism of the 1930's and 1940's. Her second collection, 'shazaya wa Ramad' (1949, Ashes and Shrapnel's) helped her launch free verse form of poetry as a new form for advent-grade poetry. [5] The form of two old hemistich one-rhymed forms had nourished unchallenged for last fourteen centuries. Experiments outside the rigid structures of Arabic literature started in the beginning of the $20^{\text {th }}$ century, but it was not until the mid-forties that poets succeeded in creating an acceptable form of free verse, new form of literary genre. Al- Malaika's book (shazaya wa Ramad) contained eleven poems and an introduction. In introduction Al-Malaika explained the advantages of the new rhyme patterns as opposed to the old traditional forms of poetry.

In 1950's Al-Malaika was among the most prominent figures of modernism, and backed this movement with her critical writings. When arguments were thrown for and against metrical poetry, with one of her best known poems, 'cholera' based on the emotional effect of the cholera epidemic that arrived from Egypt to Iraq in 1947. In her poems, 'The night is silent', 'On the depth of darkness', 'Below the silence', 'On the dead' [6], taking the subject from recent history, she, first time demonstrated the possibilities of the modern and free verse poetry. However, these poems still followed a certain rhyme scheme though little bit deviated from the conventional ones. Al-Malaika's collected poetry, 'Qadaya Ii-shir Al-mu'airri' (1962) and others attracted the continuous debate for more sophisticated expression. Which as a result developed some new principles that formulated further some of the principles of literary genre, resulted in the introduction of 'shazaya wa Ramad'.

Al-Malaika had also been a strong defender of women's rights. Her two lectures from the 1950's, about women's position in patriarchal society, women between positivity and positive morality (1953) and fragmentation in Arab society' (1954) are still typical. In the late 1960's Al-Malaika started to keep herself aloof from experimentalism and developed moralistic and conservative views. She also wrote religious poems and often used the tow hemistich form. Al-Malaika had kept a diary all through her life to keep important events registered and to portray these events and issues in her poems. She still played the 'Oudh' during her study in her youth, and liked to sing the songs of Umme kulthum and Muhammad Abdul Wahab. Al-Malaika has translated poems by writers like; Byron, Thomas gray and Robert Brooke. But during 1960 's she criticized young writers who have embraced too uncritically western models. In such a way she developed her way of composing poems revolving around the issues of common masses using free verse form. [7]
Al-Malaika, in latter life, chose herself the contents as well as the theme of the selection, and the bulk of the poems she had chosen were written 25 years ago in 1974, as is the case with all real and sincere poetry, have kept their direct appeal: 'My love', 'My rapture was a sea', and the likes. It in the course of time, changed its colors, the sockets of its eyes funning black and green. It threw its waves ahead, forged pearly, followed into springs, tended on shores, created tides, made islands, Scattered across the blue of the gulf, a blond archipelago and so on. Besides the poetry, her book also included a fascinating autobiographical sketch in which Al-Malaika revealed various aspects of her life and sorrow of the people of her vicinity.

Nazik-Al-Malaika had put a vital contribution to Arabic literature, in major concern with new prospects and perception. Her poetic output is large, but only half of it has been published in book forms or Dewans so far. Her three important collections till 1967 are: 'Ashiqat-Al-Layl' (Lover of the nights 1947) 'Shazaya wa Ramad' (Splinters and Ashes, 1949), 'Qararat-Al-Mawja' (The bottom of the wave, 1957). The major influence on Nazik Al-Malaika had been that of the English poets mournful romanticism like that of Keats, his fascination with death and its harbingers-loneliness, darkness and melancholy; the essence of poets ideas, his souls wavering between dreams and awfulness, fear pain terror and intellectualism; Schopenhauer's pessimism, the psychological atmosphere of Eliot, are all reflected in her poems. [8]

Her poetic sensibility is an extension of the romanticism and her verse necessarily bears the impression of this mood. Arab poets especially, Ali Mahmud Taha and Mahjar poets, Abu Madhi, Jibran and Nasib Arida also influenced her to a considerable extent.

Nazik-Al-Malaika poetry, mainly written in couplets and free verse form of poetry. She however, does not abandon the classical meters and even advocated their use in some cases as being more suitable than other meters; such as in cases of long poems dealing with complicated ideals.

Nazik Al-Malaika had been suffering from Parkinsonism disease for many years but died of unspecified natural causes related to old age. Her life mixed with many events, her mother's death in London invoked a terrible shock in her life, furthermore when her beloved husband died, and her heart and mentality was almost broken. Nazir Marjan the Iraqi consent in Cairo told the associated press. In a country like sectarian strife, her life and work as a poet and a literary critic were poignant reminders of Iraq's cultural renaissance in the mid-20th century. [9] Baghdad was then considered the Paris of the Middle East, and poets and artists flocked here to work. It would be recounted shortly the vigorous and prolific attributes of the poetess and her contributions at recent celebrations in Egypt on behalf of the career of the Iraqi poetess Nazik-Al-Malaika. It could also been recognized as on the pioneers of free verse, have drawn attention to the poet's connection to the country, such as her decision to live in Egypt during period of convalesce last year on this occasion. Al-Malaika, for reasons best known to her, put up a barrier against the press, which few journalists were able to penetrate. 
This meant that Al- Malaika's presence in the country went by unmarked largely. Nazika Al-Malaika said; the utterance of Bernard show in poetry and life is applicable: 'The formula are the golden formulas for important reasons, because poetry is the byproduct of events of life, life has no theory to help in smooth functioning, to follow it in compiling the events, no helping model for the colors which is used to modify the thing and feelings concerned with the events.

Nazik-Al-Malaika's verse is full of heightened feelings of the romanticism, pessimism, agony, bewilderments, imagery, love affairs and above all self-alienation. Although description of nature abound in her poetry but the subject is inevitably her own sense of sorrows imparting the society. Life of Nazik was caught in a whirlpool from which she could not escape, as in her first collection "Ashiqat-Al-layl' she faced life with frown and distress. Her poems depicted her life to be abode of pain and she rather relished it in her way. Night, representing darkness, symbolizes the friend in need or God in times of distress and release in death, also depicted her ironic aptitude. [10]

Nazik Al-Malaikas second volume of poems is regarded to be more interesting, in both the experiment in form (prosody, diction and themes) as well as content. Here she introduces the state of her inner self of poetic vision and phenomenal outbreak. This work, her finest poem, she named it as 'The unconscious' in Nihayat Al-Sullam (bottom of the stairs). Here in this poem she wrote her inner self experiments which are translated into English. Few lines of it are mentioned below.

\subsection{English Translation}

Days have passed, whose lights has been snuffed,

When we did not meet, not even in imagination.

While all alone I have been here feeding on the footsteps of the dark [11].

The third volume of poetry of Nazik is like the rest of her poetry is a cruel quarrel with herself, as in her vigorous poem 'Al-Zair Allaji Lam Yati' (The visitor who has not come). Here in this poem she preferred the theme not of dream but of reality.

Though Nazik Al-Malaika rarely indulged herself in hope and was mostly rebellious, she ended the third volume her poetry with a different note; these lines are from 'An Invitation to life'. Few lines of this poem is brought in below in Englilsh.

\subsection{English Translation}

Be angry for like you to revel and be angry.

In an enthralled rebellion and disruption.

I hated the slumber of fire in you so become a blaze [12].

During 1950's Al-Malaika was among the most prominent figures of modernism in Arabic language and literature and backed by the literary movements with her critical writings. When arguments for and against metrical poetry was prevalent, one of her best known poem appeared, namely 'cholera' as mentioned earlier. It was based on the distress confronted by the Egyptian in 1947, which latter extended to Iraq in due course of time. As a consequence her poem attracted the common people of both the countries.

Some other significant poems of Malaika are, as; 'The night is silent', 'Listen to the effect of groans', 'In the depth of darkness', 'Below the silence on the dead'. Taking the subject from recent history she first time demonstrated the possibilities of the modern verse. However, these poems still followed a certain rhyme scheme for allusive attributes and of traditional forms.

Al-Malaika had also been a strong defender of women's rights. Her two lectures from the 1950's about women's position in patriarchal society, 'women between positivity and positive morality' (1953) and 'fragmentation Arab society' (1954) [13], are still typically relevant and subjects of research.

However, in general, she was more concerned with her personal experience on nature than with nationalist issues. Moreover, she put her experiences in the topic like; experimentalism and developed more moralistic as well as conservative views. She wrote religious poems and often used the two, hemistich forms of poetry. She also translated poems by Byron, Thomas Gray and Robert Brook. She criticized young writers in 1960's who have embraced two uncritically western models disregarding the abundance of local models and issues.

Nazik also wrote essays on the constraints imposed on women in Arab society and as an early feminist she questioned the patriarchal as well as matriarchal structure that deprived many women of their choice in marriage, career and more.

Al-Malaika described her beloved husband whom she loved most and in an autobiographical essay like; 'The best colleague', and 'companion and friend' died in 2005 and she survived with a son from him.

It was Naziks writing and that of a handful of contemporaries that popularized free verse, and she gradually became a celebrated figure of this kind, and her poems incorporated with the subject of academic studies. Much of her work dealt with alienation and the fear of fading into oblivion. Her poem 'Lament of worthless women' (1952) suggests the universal fear of being forgotten after death where she left no cheek turned pale no lip trembled. Though as per the trend of Arabic poetry in $20^{\text {th }}$ century Arab poets had already began controversial experiments outside the rigid classical form, in which each verse ends with the same rhyme scheme and each line has the same number of beats.

Here in bellow, some thematic aspects of Naziks poetry have been discussed.

\subsection{Ashiqat Al-layl}

Nazik published the collection of her emotional poetry in this segment. Here she felt free from conservative views by heart and style. So the poetry in this collection is centralized on the development of new friend and establishment of new poetic picture with the help of romanticism of the contemporary poets. She, in her poems described night and day in a vivid manner because night is full of wonderful starts and the moon is lighting that symbolized the calmness of dreams. She qualified the ode in 'Ashiqat Al-Layl' fully with 
sorrow, unhappiness and mindset. But in reality the narrowness of the society around her was oppressing her attitude and enthusiasm. Her collection of poems (dewan) 'Ashiqut Al-Layl' comprised of 29 odes on old traditional standard and eight on modern style of poetic aptitude. [14] Two poems of this collection are translated into other languages.

\subsection{Shazaya Wa-Ramad (1949)}

Al-Malaikas second dewan was published in 1949, is concerned with innovative ideas and fruitful suggestions for new comers. Here she invited the modern poets towards free verse poetry though it attracted little response in Arabian Countries. She said, it was perhaps the skill, famous after publication of 'Ashiqat Al-Layl' till she got new poetic trends in her life other than the trend of 'Ashiqat Al-Layl'. So, here she deviated from the guide of sorrow of darkness of night to new adventure which is the compassion. When 'Shazaya wa Ramad' [15] was published in $23^{\text {rd }}$ August 1949, it inspired strong attitude in literature and culture in Iraq and abroad. The main reason of her propagation towards free verse poetry was to put rhymes and the names of meters. Here in this, she invited modern poets of Arabic towards development of poetic line and language pattern. The poem 'Shazaya wa Ramad' consisted of 32 odes, six of it in accordance with old style and 26 according to modern method. The poem 'Qararat Al Mawjah'(1957) depicted this aspect also.

\subsection{Qararat Al Mawjah 1957}

Nazik published her third diwan in 1957; 'Qararat Al-Mawjah' founded the new line and style in Arabic poetry. She, in this poem, composed as symbolic odes on legendary issues, socio-political agendas, matter of national importance and the likes. This poem got warm welcome as well as response in the world of literature in general and Arabic in particular. It had a significant proposition in the realm of poetry and the atmosphere of litterateurs. [16]

\subsection{Shajarat Al Qamar}

In 1968, Nazik published her poetic collection 'Shajarat Al Qamar' which is far different from 'Qararat Al Mawjah' because this collection exaggerates the loneliness of life and happiness because the artistic tools were different in the Cartier collection. 'Shajarat Al Qamar' [17] came on a natural composition of styles and sensible pictures where Al-Malaika displayed the impression of her sense and good pictures in the shadow of magic and the wonderful creativity.

Nazik had other poetic writings as well, like:

(2.6.1) Yugayiru Alwanahae Al Bahru: Baghdad 1977.

(2.6.2) Lis salat wa Al Thawrah: Beirut 1978. [18]

Miss. Malaika was one of a small group of Iraqi poets who broke away from classical Arab poetry with its rigid metric and rhyme schemes. Influenced by the writing of Shakespeare, Byron and shelly as well as by classical Arabic poets. These poets took up modern topics and used lyrical language that spoke with the immediacy of life on the Arab street. The meaning of one of her depression full poem is as.

\subsection{English Translation}

Oh mother, a rattle, tears and darkness.

Blood gushed out, and the stabbed body trembled.

Oh mother, heard only by the executioner.

Tomorrow the dawn will come and roses wills weak up. [19]

Here some of the prominent works of the poetess Nazik

Al-Malaika are mentioned below:

(2.7.1) Ashiqal Al-Layl, (The lover of night), 1947.

(2.7.2) Shajaya wa Ramad, 1947.

(2.7.3) Al-mara baina starafain, Al-salbiyya wa I-akh-laq, 1953.

(2.7.4) Al-Tajzi iyya fi I-mujitama Al-Arabi, 1954.

(2.7.5) Qararat Al Mawaya, 1957.

(2.7.6) Qaday I-shir Al-muasir, 1962.

(2.7.7) Al-sanomaa wat-shurfa Al-Hamras, 1966.

(2.7.8) Shyarat Al-qamar, released in 1968.

(2.7.9) Ma sat Al-hayat wa ugniya li-1-in-san, 1970.

(2.7.10) Al-tayiiyya fi-I-muytama' Al-arabi, 1974.

(2.7.11) Yugayyir Alwana-hu-I bahr, 1976.

(2.7.12) Lil salat wa-I-tawra, 1978.

(2.7.13) Sykologia Al-Shir, 1979.

(2.7.14) Youghiyar Alunah Al-Bahr, 1999.

(2.7.15) Al-Azmal Al-Nathriya Al-kamila, two volumes, 2002.

(2.7.16) Al Aamal Al-Shiriya Al-kamila, 2002. [20]

\section{Result}

It is believed that the poetry of Nazik and Fedwi are interpreted as spontaneous Romantic in inference and imagination, it is subjective composition in its place. Both fedwi and Nazik, of course practiced and developed free verse poetry, as well in the code of living socialism. Both the poetess is pessimist for different reasons. As per as Fedwi Tuqan is concerted, she lost her brother in her young age. Thus she mixed her poetry with living picture which adds an open struggle. Likewise, Nazik graced her poetry with her sorrowful mind in her Article 'Al shri fi hayati' the explainer of this, enumerated the reasons. The reasons of her grievance which displayed in 'Ashiqat al Layl' are many. One of which is her depression invoked by the death which the human being are subjected to. She did not agree with that generally, and through it like anything totally. The second reasons of her sorrow, is her hate for British colonialism and the hate for Iraqi government acted by Nuri Al Sayeed and Abd al-Ilah. The third reason for her grievance is her status along the other women of the Arabian Society, and her deprivation from culture and freedom and peoples care or importance to women. The fourth reason of her depression, mindset and her humiliation was provoked by gender biasness, and her husband's belief that love corrupts the spirit of human being behind the feeling which on the other hand is a philosophy portrayed in her ode 'Madinat al Hubb' in 'Ashiqat al Layl'. 


\section{Discussion}

Some valuable things have been revealed in this brief article that has been thought to be vital for research and analysis. Nazik Al-Malaika happened to be untraditional in her attitude, romance, logic, views, tragedies and struggle life. Malaika's poetry was not intentional or artificial rather it seemed to be natural as she violated all the traditional system of poetry, i.e. classicism, neo-classicism, symbolism and romanticism. She, on the contrary adopted free verse poetic line at her matured state of career. Nazik's poetry is outcome of her grievances, tragedies, sorrows, emotions and more which are very important in the life of a matured as well as social poetess, portray issues of common people rather than conventional. Incorporation of common issues of general masses of her homeland, Iraq and Egypt is a unique aspect of her work.

Suggestions may be made for the readers as well as the researchers, having interest in the topic may study the life, career and contribution of Al-Malaika to Arabic literature to find out her unique style and technique of her poetry. Studies and researches may be done to find out her critical approach in poetry and other works in comparison with her contemporaries or so. Readers and researchers may collect more information about her works and find out; whether there remained any manuscript of her that remained unpublished, if found then publish it as one can expand own knowledge with the help of her writings. Her contributions to Arabic literature are primly categorized as poetry, criticism, short-story and others.

\section{Conclusion}

In concluding words it is to be remembered that Naziks technique in free verse and her favorite meters are 'Al-sari' Al-khafif and 'Al-mutaqarib'. She wrote her free verse poem 'Al-kulira', with the vivid illustration of people died in epidemic cholera. In this poem she adopted modern form of poetic devices decrying the traditional form of elegies in respect of royal and elite group. And that is why she is considered to be the poetess of common people. Nazik-Al-Malaika said; she was moved by the tragic loss of lives in the Cairo epidemic, but when she composed her poem in the usual meters. She felt that its time did not match the depth of her feelings. A week later when the radio broadcasted that six hundred victims were dying daily, she made another attempt only to tear up her poem. When the death toll was a thousand a day and the bodies were reportedly being piled on horse drowns carriages, then she took help of the meter 'Mutadarak' as of horse hoof', suggested itself the pattern; failun, failun, failun. She composed her poetry varying the length of the lines heralding the birth of free verse, corporation of common issues and free verse developed mutually in her composition. Nazk-Al-Malaika's verses are rich in imagery, symbols, myths and quotations. She often repeated words, lines, verses, interrogations and even phrases and was masterful in describing subtle shades of feelings. Her fortune is cadence which she varies according to her moods. The works of Nazik-Al-Malaika has been translated into many a language and she is a personality to be read, studied and researched.

\section{References}

[1] Alissa. J. Rubin, Internet sources, 27 June 2007.

[2] Abdul Moneim, Al-Ahram, June 27, 2007, issue no. 851.

[3] Ismail Ajuddin, Nazik Al-Malaika, Page-116-121.

[4] Badawi M. M., A critical introduction to modern Arabic poetry, p-144.

[5] Mahdi Ismat, Modern Arabic Literature, Hyderabad, p-224.

[6] Al-Malaika Nazik, Al-Sh'iru fi Hayati, p 183-184.

[7] Al-Hanri Ibrahim, Harkat Al-Naquad Al-Hadith wa Al-Muasir fi Al-Sh'ir Al-Arabi, Beirut, T, 1, Muassasat Al-Risalah, 1984.

[8] Abu Sad Ahmed, Al-Sh'ir Wa Al-Shuwara fi Al-Iraq, 1900-1958, Dirasatu wa Muktaratu Lubnani, Dar Al-Ma'arif, 1959.

[9] Al-Malaika Nazik, Al-Shamsu Al-Lazi Wara Al-Qummah (Short story), Al-Majlis Al-A'ala Li Al-Thaqafah, 1998.

[10] Matlub Ahmed, Al-Insaniatu fi Shi're Nazik, p35-40, Mujallat Al-Aqlam, Bagdad, Feb. 1992.

[11] Balata I'sa, Badre Shakir Al-Sayyab, Bagdad, 1987.

[12] Amin Qasim, Tahriru Al-Mar'ah, Cairo $1316 \mathrm{AH}$.

[13] Amin Qasim, Al-Mar'ah Al-Zadidah, Egypt 1900.

[14] Nash'at Kamal, Abu Shadi wa Harkat Al-Taz, 1967.

[15] Samirai Mazid Ahmed, Nazik Al-Malaika, Al-Mawzah Al-Qalqah, Bagdad 1975.

[16] Fahmi Mahir Aasam (D), Al-Harkat Al-B'ath fi Al-Shir Al Arabi Al-Hadith, Egypt 1961.

[17] Munjir Al-Juburi, Shuwarau Iraqiuun, Iraq Republic 1077.

[18] Musa Munif, Nazriyyat Al-Shi'r Inda Al-Naqqad fi Al-Adab Al-Arabi.... Lebanon, 1984.

[19] Amir Zund Bahar, Nasime Magrib, India 1963.

[20] Al-Ahram, Nazik Al-Malaika, Issue-851, 28th June 2007. 